\title{
Penanggulangan Bencana sebagai Soft Power dalam Diplomasi Indonesia
}

\section{Ratih Herningtyas}

Jurusan IImu Hubungan Internasional, Fakultas IImu Sosial dan Politik, Universitas Muhammadiyah Yogyakarta

Ringroad Barat Tamantirto, Kasihan, Bantul 55183

Email: ratih_herningtyas@umy.ac.id

\begin{abstract}
This paper aims to describe how the issue of disasters in Indonesia can be modified into a positive social capital to solve social, economic, political and social culture's problems in disaster prone areas. This paper found that Indonesia's disaster managements get worldwide recognition and increases Indonesia's competitiveness toward other countries. These recognitions become the sources of Indonesia's soft power, and can be used as a strategic instrument to build regional cooperation and international collaboration to improve infrastructure that can reduce the degree of disasters' material and immaterial losses.

Keywords: disaster, Indonesia, soft power
\end{abstract}

\begin{abstract}
Abstrak
Tulisan ini bertujuan untuk menggambarkan bagaimana isu bencana di Indonesia dapat dimodifikasi menjadi modal sosial yang positif dalam menyelesaikan masalah sosial, ekonomi, politik, dan sosial budaya di daerah rawan bencana. Tulisan ini menemukan bahwa manajemen bencana Indonesia mendapatkan pengakuan dunia, dan meningkatkan daya saing Indonesia terhadap Negara lain. Pengakuan ini menjadi sumber soft power Indonesia dan dapat digunakan sebagai alat strategis untuk membangun kerjasama daerah dan kolaborasi internasional untuk meningkatkan infrastruktur yang mampu mengurangi taraf material bencana dan kerugian immaterial.

Kata Kunci: bencana, Indonesia, soft power
\end{abstract}

\section{PENDAHULUAN}

Bencana menjadi salah satu isu kontemporer dalam pergaulan internasional yang membutuhkan perhatian khusus, karena dampak yang ditimbulkannya mengakibatkan penderitaan bagi masyarakat baik berupa korban jiwa manusia, kerugian harta benda maupun kerusakan lingkungan. Selain itu, bencana alam juga membuat kerusakan atas hasil-hasil pembangunan yang telah dicapai seperti kerusakan sarana dan prasarana, fasilitas umum serta berbagai kerugian lainnya. Bencana alam juga merupakan sebuah ancaman yang tidak dapat diprediksi oleh semua negara. Setiap negara, baik negara miskin, negara berkembang dan tidak terkecuali negara maju juga dapat menghadapi ancaman bencana.

Indonesia merupkan salah satu negara yang memiliki potensi bencana alam tertinggi di dunia. Menurut United Nations International Stategy for Disaster Reduction ( UNISDR ), yaitu badan PBB untuk Strategi Internasional Pengurangan Risiko Bencana, Indonesia rawan mengalami berbagai bencana seperti gempa bumi, tsunami, letusan gunung berapi, banjir, tanah longsor, kekeringan, dan kebakaran hutan. Bahkan untuk beberapa jenis bencana alam, Indonesia menduduki peringkat pertama dalam paparan terhadap penduduk atau jumlah manusia yang menjadi korban meninggal akibat bencana alam. Selama tahun 2008 saja, Walhi mencatat telah terjadi 359 bencana alam 
yang menimpa sebagian wilayah di Indonesia, meliputi banjir, tanah longsor, dan gempa bumi. ${ }^{1}$

Sementara itu berdasarkan data yang dilansir BNPB, kejadian bencana yang terjadi di Indonesia mengalami peningkatan dari tahun ke tahun. Pada tahun 2008 saja misalnya, terdapat peningkatan 46,66 \% dari tahun sebelumnya, yaitu dari 888 kejadian bencana pada tahun 2007 menjadi 1.306 kejadian bencana di tahun 2008..$^{2}$ Sementara, di tahun 2009 terdapat peningkatan sejumlah 652 kejadian bencana atau terdapat peningkatan kejadian bencana sebanyak 50\% dari tahun 2008. Kerugian akibat bencana setiap tahunnya mencapai lebih dari Rp10 triliun. Angka itu tidak termasuk kerugian akibat bencana skala besar seperti gempa dan tsunami di Aceh dan Mentawai, serta erupsi Gunung Merapi beberapa waktu lalu. ${ }^{3} \mathrm{Hal}$ inilah yang menasbihkan Indonesia sebagai negara dengan risiko dan dampak bencana alam tertinggi di dunia.

Melihat kenyataan di atas, wajar kiranya jika sebagian masyarakat maupun pemerintah memandang fenomena terjadinya bencana sebagai sesuatu yang negatif, peristiwa yang membawa kehancuran dan menyisakan cerita traumatis yang akan terus mempengaruhi kehidupan di masa-masa yang akan datang. Namun pemaknaan secara negatif terhadap kondisi geografis dan topografis yang rawan bencana alam justru akan melahirkan sikap dan kebijakan yang lari dari kenyataan dan realitas kehidupan.

Tulisan ini akan memaparkan bagaimana isu bencana di Indonesia dapat dimodifikasi menjadi modal sosial positif untuk menyelesaikan problem sosial, ekonomi, politik dan sosial budaya di daerah rawan bencana. Bencana alam memiliki keunikan untuk dikapitalisasi sebagai instrumen strategis untuk membangun kolaborasi kerjasama regional maupun internasional untuk meningkatkan infrastruktur yang dapat mengurangi derajat kerugian material maupun immaterial dari bencana yang sewaktu-waktu terjadi.

\section{PEMBAHASAN}

SOFT POWER DAN DIPLOMASI BENCANA : SEBUAH KERANGKA KONSEPTUAL

Berbagai persoalan dunia termasuk didalamnya persoalan bencana dan perubahan iklim telah banyak disadari para pemangku kebijakan tidak memungkinkan jika diselesaikan dengan penggunaan hard power (kekuatan militer). Sebaliknya, penggunaan soft power justru semakin menguat dalam upaya menyelesaikan permasalahan dunia. Hal itu terbukti dengan dilaksanakannya berbagai dialog antar-umat beragama serta kerjasama di bidang sosial dan budaya, sebagai salah satu perwujudan soft power yang dinilai dapat meredakan ketegangan yang terjadi di berbagai belahan dunia dewasa ini. Bantuan kemanusiaan pada daerah-daerah bencana telah digunakan sebagai soft power untuk menunjukkan eksistensi bangsa. Bantuan kemanusiaan tersebut seringkali tidak memerlukan prasyarat standar normal aturan yang berlaku seperti harus sudah ada hubungan diplomatik antarnegara sebelumnya.

Joseph S. Nye, Jr dalam bukunya Soft Power : the Means to Success in World Politics, membagi konsep tentang power menjadi Hard power dan Soft power dan memaparkan argumentasinya mengapa soft power adalah elemen yang penting dalam sebuah kebijakan luar negeri dan hubungan internasional yang tidak bisa diabaikan. Dalam definisi Nye, soft power adalah '...its ability to attract others by the legitimacy of State's policies and the values that underlie them. ${ }^{4}$

Bagi Nye, dalam menjalankan peran internasionalnya, sebuah negara seharusnya mengedepankan daya tarik dan persuasi. Dengan kata lain. soft power adalah kemampuan untuk membuat pihak lain menjalankan apa yang kita inginkan tanpa kita harus menggunakan kekerasan atau membayar melainkan melalui daya tarik. ${ }^{5}$ Dalam soft power pihak lain melakukan apa yang kita inginkan karena keinginan dari dirinya sendiri berkat kemampuan yang tidak bersifat kekerasan yang kita miliki. Lawan dari soft power sebagai konsep atau sebagai strategi adalah hard power, yang mencakup berbagai langkah atau tindakan yang diambil untuk memaksa atau mengancam negara lain untuk tunduk. ${ }^{6}$ Tindakan tersebut dapat meliputi ancaman serangan militer atau embargo ekonomi (sticks). Ancaman tersebut dapat juga diiringi dengan janji perlindungan militer atau 
pengurangan hambatan perdagangan (carrots).

Menurut Nye, sumber bagi terciptanya soft power sebuah negara dapat diperoleh melalui :

The resources that produce soft power for a country include its culture (where it is attractive to others); its values

(where they are attractive and not undercut by inconsistent practices) and its policies (where they are seen as inclusive and legitimate in the eyes of others) ${ }^{7}$

Sebuah negara dapat menggunakan berbagai instrumen di lingkungannya sebagai sumber soft power, seperti diplomasi publik, media penyiaran, program pertukaran seperti kebudayaan atau pendidikan, bantuan-bantuan pembangunan kontak kerjasama militer seperti pelatihan dan latihan bersama, bantuan bencana bahkan kredibilitas pemerintah dalam penanggulangan bencana. ${ }^{8}$

Di sisi yang lain, menurut Louise K. Comfort, isu bencana sekarang ini menjadi isu yang sangat krusial bagi peningkatan kualitas kesejahteraan manusia. Bencana harus didefinisikan secara lebih luas, tidak hanya sebatas isu bencana alam semata namun juga bencana penyakit menular yang memiliki efek global seperti endemic virus Flu Burung, Flu Babi, ataupun isu pemananasan global. Pendefinisian bencana sebagai isu global diharapkan akan dapat meningkatkan emphati dari masyarakat dunia untuk terlibat bersama menyelesaikan problem bencana.

Disaster Diplomacy examines the role of disasterrelated activities not just in international affairs and international relations, but also in political conflicts not involving more than one independent state. Disaster Diplomacy also embraces a wide definition of “disaster", not just rapid-onset events such as earthquakes and industrial explosions, but also events which are more diffuse in space and time such as droughts, epidemics, and global changes. These latter events have been termed "chronic disasters", "creeping changes", and "disaster conditions" amongst other terms. ${ }^{9}$

Sebuah kajian yang dilakukan oleh I. Kelman menunjukkan bahwa bencana tidak selalu menjadi faktor yang buruk bagi masyarakat, namun dalam batas tertentu dapat dikelola untuk menyelesaikan persoalan-persoalan politik dan konflik yang selama ini tak terpecahkan, baik dalam konteks persoalan dalam level nasional maupun antara negara. ${ }^{10}$ Menurut Kelman, bencana justru memberikan ruang yang besar bagi pihak-pihak yang memiliki potensi sebagai daerah rawan bencana untuk mencari ruang yang bisa dikerjakan untuk mengurangi risiko yang ditimbulkan dari bencana alam itu sendiri. Ia juga menjelaskan bahwa bencana alam dapat dikelola untuk menjadi ruang bagi peningkatan kerjasama politik, ekonomi, sosial budaya yang lebih luas. ${ }^{11}$ Negara-negara yang tergolong sebagai daerah yang rawan bencana atau potensial mengalami bencana alam, yang sebelumnya tidak melakukan kerjasama yang intensif, bahkan cenderung bermusuhan secara politik, kemudian memilih melakukan kerjasama untuk mengurangi risiko dan dampak bencana.

Studi yang sedikit berbeda dilakukan oleh Weizhun. Weizhun menyebut penggunaan isu terkait dengan bencana sebagai moda interaksi dengan negara lain sebagai diplomasi bencana. Menurut Weizhun, pertumbuhan ekonomi China yang progresif dalam 10 tahun terakhir ini tidak dapat dilepaskan dari upaya kapitalisasi pemerintah China untuk mengelola bencana alam, sebagai sarana membangun kerjasama internasional dengan negara-negara yang selama ini mencurigai kebijakan China yang interventif. China bukan lagi dianggap sebagai kekuatan yang dianggap musuh, karena China justru menunjukan politik empati untuk terlibat dalam kerjasama dengan negaranegara yang rawan bencana alam. Dari sinilah kemudian investasi China dapat ditanam di negaranegara yang selama ini menolak investasi modal dari China.

The practice of Disaster Diplomacy has a great influence and actual values on improving national and international interests. Disaster Diplomacy is flexible and multiform yet uncertain and there are some restrictions in the process of diplomatic practice. Disaster Diplomacy can also promote the Chinese role "as a responsible and powerful country". ${ }^{12}$ 
Dari penjelasan ini tampak bahwa isu bencana dan penanggulangannya dapat menjadi modal bagi pelaksanaan diplomasi sebuah negara yang lebih efektif dan mendatangkan pencapaian kepentingan yang lebih maksimal.

\section{INISIASI STRUKTURAL DALAM PENANGGULANGAN BENCANA}

Isu bencana alam telah menjadi bagian yang tak terpisahkan dari kehidupan sehari-hari masyarakat Indonesia. Berada di wilayah yang disebut sebagai ring of fire mengharuskan masyarakat senantiasa waspada terhadap ancaman bencana alam yang sewaktu-waktu datang. Kondisi ini menjadikan pemerintah memiliki tanggung jawab untuk mengkoordinasi antisipasi maupun penanggulangan bencana alam melalui pembentukan Badan Nasional Penanggulangan Bencana (BNPB).

Pembentukan BNPB melalui sebuah proses sejarah yang panjang, diawali sejak deklarasi kemerdekaan 17 Agustus 1945. Perkembangan zaman dan kebutuhan serta perubahan persepsi bencana turut memberi andil terhadap format kelembagaan penanggulangan bencana maupun teknis pelaksanaannya. Secara umum, perkembangan tersebut dapat dibagi berdasarkan periode sebagai berikut : ${ }^{13}$

1. Periode Awal Kemerdekaan-1966

Pada awal pembentukan lembaga penanggulangan bencana, pemerintah membentuk Badan Penolong Keluarga Korban Perang (BPKKP) yang memiliki tugas utama untuk menolong para keluarga dan korban perang kemerdekaan

2. $1966-1967$

Untuk menanggapi peristiwa bencana alam, pemerintah membentuk Badan Pertimbangan Penanggulangan Bencana Alam Pusat (BP2BAP) melalui Keputusan Presiden Nomor 256 tahun 1966.

3. $1967-1979$

Kejadian bencana alam terus meningkat, maka penanganan secara sungguh-sungguh dan terkoordinasi sangat dibutuhkan. Untuk itu, pada tahun 1967 presidium kabinet membuat
Keputusan Nomor 14/U/KEP/I/1967 yang membentuk Tim Koordinasi Nasional Penanggulangan Bencana Alam (TKP2BA).

4. $1979-1990$

Pada periode ini tim koordinasi nasional penanggulangan bencana alam ditingkatkan menjadi Badan Koordinasi Nasional Penanggulangan Bencana Alam (Bakornas PBA) yang dikoordinasikan oleh Menteri Sosial dan dibentuk dengan Keputusan Presiden Nomor 28 tahun 1979. Sebagai penjabaran operasional dari Keputusan Presiden tersebut, Menteri Dalam Negeri dengan instruksi no. 27 tahun 1979 membentuk Satuan Koordinasi Pelaksanaan Penanggulangan Bencana Alam (SATKORLAK PBA) untuk setiap provinsi.

5. $1990-2000$

Pada periode ini mulai disadari bahwa bencana itu bukan saja bencana alam, tetapi juga bencana karena ulah manusia, seperti kecelakaan transportasi baik darat, laut, maupun udara dan sering kali menimbulkan korban jiwa yang besar. Selain itu sektor industri turut meningkatkan risiko bencana akibat ulah manusia ini. Itulah alasan dibalik penyempurnaan Badan Koordinasi Nasional Penanggulangan Bencana Alam menjadi Badan Koordinasi Nasional Penanggulangan Bencana (BAKORNAS PB). Berdasarkan Keputusan Presiden Nomor 43 tahun 1990. Lingkup pekerjaan dari BAKORNAS PB ini diperluas, tidak hanya menangani bencana alam tetapi juga bencana akibat ulah manusia. Hal ini di tegaskan kembali dalam Keputusan Presiden Nomor 106 tahun 1999. Penanggulangan bencana memerlukan penanganan lintas sektor, lintas pelaku, dan lintas disiplin yang terkoordinasi.

6. $2001-2005$

Setelah Indonesia mengalami krisis multidimensi dan bencana alam yang silih berganti serta berbagai konflik sosial, maka timbul permasalahan baru yaitu pengungsi yang perlu penanganan khusus. Untuk itu BAKORNAS PB pun dikembangkan menjadi Badan Koordinasi Nasional 
Penanggulangan Bencana dan Penanganan Pengungsi (BAKORNAS PBP) dengan Keputusan Presiden Nomor 3 yang diperbarui dengan Keputusan Presiden Nomor 111 tahun 2001.

Sejalan dengan pelaksanaan otonom daerah, dimana kewenangan penanggulangan bencana menjadi tanggung jawab daerah, pemerintah pusat mulai meningkatkan kemampuan pemerintah daerah dan masyarakat setempat untuk dapat secara mandiri mengatasi permasalahan bencana didaerah bersangkutan.

7. $2005-2008$

Menyusul tragedi gempa dan tsunami di Aceh dan sekitarnya, keluar Peraturan Presiden Nomor 83 tahun 2005 tentang Badan Koordinasi Nasional Penanganan Bencana. Badan ini selain memiliki fungsi koordinatif juga didukung oleh pelaksana harian sebagai unsur pelaksana penanggulanagn bencana. Sejalan dengan itu, pendekatan melalui paradigma pengurangan resiko merupakan jawaban yang tepat untuk melakukan upaya penanggulangan bencana pada era otonomi daerah. Dalam paradigma ini, setiap individu diperkenalkan dengan berbagai ancaman yang ada di wilayahnya, bagaimana cara memperkecil ancaman dan kerentanan yang dimilki, serta meningkatkan kemampuan masyarakat dalam menghadapi ancaman.

\section{Sejak 2008}

Peraturan presiden RI No. 8 tahun 2008 tentang Badan Nasional Penanggulangan Bencana (BNPB) yang pembentukannya merupakan amanat dari Undang-Undang Nomor 24 tahun 2007 tentang Penanggulangan Bencana.

BNPB sebagai badan khusus penanggulangan bencana di Indonesia mengambangkan suatu lingkaran manajemen bencana (disaster management cycle) yang melibatkan dua kegiatan besar. Pertama adalah sebelum terjadinya bencana (pre event) dan kedua adalah setelah terjadinya bencana (post event). Kegiatan setelah terjadinya bencana dapat berupa disaster response/emergency response (tanggap bencana) ataupun disaster recovery. Kegiatan yang dilakukan sebelum terjadinya bencana dapat berupa disaster preparedness (kesiapsiagaan menghadapi bencana) dan disaster mitigation (mengurangi dampak bencana). Ada juga yang menyebut istilah disaster reduction, sebagai perpaduan dari disaster mitigation dan disaster preparedness. ${ }^{14}$ Sementara itu kegiatan-kegiatan yang dapat dilakukan sebelum bencana dapat berupa pendidikan peningkatan kesadaran bencana (disaster awareness), latihan penanggulangan bencana (disaster drill), penyiapan teknologi tahan bencana (disaster-proof), membangun sistem sosial yang tanggap bencana, dan perumusan kebijakan-kebijakan penanggulangan bencana (disaster management policies).

Bersamaan dengan dimulainya pelaksanaan Hyogo Framework for Action (Kerangka Aksi Hyogo - HFA) 2005 - 2015, Indonesia juga mulai membangun Sistem Nasional Penanggulangan Bencana, mulai dari legislasi, kelembagaan, perencanaan, pendanaan dan pengembangan kapasitasnya, agar penyelenggaraan penanggulangan bencana, termasuk pengurangan risiko bencana, dapat berjalan secara terpadu dan menyeluruh.

Berbagai capaian yang telah dilakukan Indonesia termasuk lahirnya Undang Undang No. 24 Tahun 2007 tentang Penanggulangan Bencana, terbentuknya Badan Nasional Penanggulangan Bencana dan Badan Penanggulangan Bencana Daerah (BNPBD) di tingkat provinsi dan berbagai kabupaten/kota, tersusunnya Rencana Nasional Penanggulangan Bencana (20102014), Rencana Aksi Nasional Pengurangan Risiko Bencana (2010-2012), dimasukkannya pengelolaan bencana ke dalam RPJMN (2010-2014) sebagai salah satu prioritas pembangunan nasional, dan sebagainya. ${ }^{15}$

Bentuk komitmen Indonesia terhadap HFA juga diwujudkan dengan terbentuknya Platform Nasional Pengurangan Risiko Bencana (Planas PRB) yang merupakan wadah bagi para pemangku kepentingan PRB (media, organisasi masyarakat, pemerintah, akademis, lembaga usaha dan organisasi internasional) untuk bersinergi dalam PRB karena PRB adalah "everybody's business". Di tingkat lokal, beberapa forum 
PRB juga sudah dibentuk. Pemerintah terus berupaya mendukung kemajuan penanggulangan bencana di tingkat daerah termasuk dengan pembuatan peta-peta risiko untuk digunakan dalam menyusun rencana pembangunan hingga penguatan kelembagaan melalui penyusunan rencana kontinjensi dan pelatihanpelatihan untuk kesiapan tanggap darurat. ${ }^{16}$

\section{PENANGGULANGAN BENCANA ALAM DI INDONESIA SEBAGAI SOFT POWER}

BNPB dan pelembagaan kegiatan penanggulangan bencana dalam perkembangannya menunjukkan kinerja yang baik dan memberikan dampak yang positif bagi pencitraan pemerintahan di mata masyarakat Internasional. Penanggulangan bencana dibawah koordinasi BNPB tersebut menghasilkan sebuah soft power yang dapat dimanfaatkan pemerintah untuk melancarkan diplomasi yang efektif dalam mengembangkan kerjasama dengan negara lain untuk pencapaian tujuan dan kepentingan nasional.

Selain BNPB, masyarakat dunia telah memandang bahwa penanggulangan bencana di Indonesia mengalami kemajuan yang luar biasa. Pasca tsunami Aceh 2004, dari negara yang belum memiliki sistem dan perangkat penanggulangan bencana, setelah itu memiliki sistem nasional yang cukup lengkap. Dalam kurun waktu sekitar 4 tahun setelah ditetapkannya UU Nomor 24 Tahun 2007, Indonesia dinilai oleh banyak negara sebagai negara yang maju dalam penanggulangan bencana. Bandingkan dengan Korea Selatan yang perlu waktu membangun selama lebih dari 15 tahun untuk memiliki sistem nasional penanggulangan bencana di Korea Selatan.

Upaya untuk membangun ketangguhan terhadap bencana di tingkat komunitas telah dilakukan oleh berbagai organisasi masyarakat/NGOs dalam bentuk Community Based Disaster Risk Reduction (CBDRR) projects. CBDRR dilakukan dengan pemahaman bahwa komunitas/masyarakat lokal memiliki kearifan dan pengetahuan lokal. Oleh karena itu mereka adalah pihak yang tepat dalam mengidentifikasikan ancaman dan risiko yang dihadapi serta upaya mitigasi yang diperlukan untuk mengantisipasinya.
Sistem peringatan dini untuk berbagai ancaman telah dibangun, seperti system peringatan dini tsunami (INA TEWS), gunung meletus, banjir, dan tanah longsor. Upaya untuk mengarusutamakan PRB kedalam pendidikan juga sudah dimulai sejak 2008. Kementerian Pendidikan dan Kebudayaan, dengan didukung berbagai komponen yang bergerak dalam bidang pendidikan dan pengurangan risiko bencana, menyusun strategi untuk pengarusutamaan PRB dalam bentuk modul ToT yang dapat digunakan sebagai panduan bagi para guru dalam menjelaskan mengenai ancaman, pengetahuan dasar tentang pengurangan risiko bencana, kesiapsiagaan, dan sebagainya. Indonesia juga berpartisipasi dalam kampanye global "One million safe schools and hospitals", dimana sejumlah 13.500 sekolah dan 133 rumah sakit di Indonesia berkomitmen untuk membangun sekolah dan rumah sakit yang aman dari bencana. Komitmen Pemerintah untuk pengurangan risiko bencana juga ditandai dengan meningkatnya pendanaan untuk PRB dalam lima tahun terakhir, terutama dana PRB yang meningkat secara signifikan yaitu 2,14 juta USD pada tahun 2010 menjadi 21,4 juta USD pada tahun 2011. ${ }^{17}$

Indonesia, sebagai laboratorium untuk penanggulangan bencana, juga telah menjadi referensi bagi negara lain. Berbagai delegasi dari negara lain telah datang ke Indonesia untuk belajar mengenai kemajuan/capaian Indonesia dalam PRB dan PB dan ingin melakukan/ menggunakan upaya yang serupa dengan yang telah digunakan oleh Indonesia (contohnya Data dan Informasi Bencana Indonesia/ DIBI, Platform Nasional PRB, Undang Undang No. 24/2007 tentang Penanggulangan Bencana, dan sebagainya). Capaian Indonesia dalam bidang pengurangan risiko bencana menunjukkan pentingnya kemitraan dalam mengimplementasikan PRB. Di bawah arahan dan koordinasi BNPB, berbagai mitra PRB, seperti Safer Communities for Disaster Risk Reduction (SCDRR), Global Facility for Disaster Risk Reduction (GFDRR), Australia- Indonesia Facility for Disaster Reduction (AIFDR), DIPECHO, JICA, United Nations Country Team, UN ISDR, dan lainnya., turut memberikan kontribusi yang signifikan bagi 
kemajuan PRB di Indonesia.

Upaya-upaya dalam mempromosikan PRB dan kesadaran bersama dalam PRB secara berkelanjutan dilakukan secara giat oleh badan penanggulangan bencana dan stakeholder, termasuk sektor swasta, civil society, dan komunitas di seluruh Indonesia. Melihat kenyataan bahwa masyarakat terpencil seringkali menjadi kelompok yang rentan sebagai dampak bencana, sehingga kesadaran akan PRB perlu mendapatkan perhatian utama. Upaya dan kerja keras Pemerintah Indonesia ini dibantu melalui kerjasama teknis dengan mitra internasional, khususnya UNISDR, UNDP, AIFDR, Bank Dunia, JICA, dan negara-negara donor. Sementara itu, insitutsi nasional, LSM, universitas dan sektor swasta juga sangat mendukung dalam mewujudkan tindakan-tindakan dalam PRB. Hal - hal tersebut diatas merupakan sumber-sumber soft power Indonesia yang dapat dimanfaatkan dan pergaulan internasional.

Perkembangan pengelolaan penanggulangan bencana di Indonesia telah menarik perhatian dan kepedulian badan-badan dunia termasuk Perserikatan Bangsa-Bangsa (PBB). Salah satu perhatian PBB terhadap isu penanggulangan bencana terutama yang telah dilakukan pemerintah Indonesia adalah Indonesia Tsunami Early Warning Center (Ina TEWS) yang mampu membangun sistem dan buoy untuk peringatan tsunami dengan kemampuan perkiraan 8 menit setelah gempa bumi. Data dan Informasi Bencana Indonesia (DIBI) diakui sebagai instrumen sistem informasi bencana terbaik di Asia Pasifik dan dijadikan model untuk negara-negara lain serta pemberian penghargaan Global Champion for Disaster Risk Reduction dari PBB kepada Presiden Susilo Bambang Yudhoyono pada Mei 2011, sebagai pengakuan dan harapan akan strong leadership Indonesia dalam penanggulangan bencana khususnya untuk kampanye pengurangan risiko bencana. Pengakuan dunia terhadap capaian Indonesia dalam penanggulangan bencana merupakan bukti bahwa bangsa Indonesia memiliki daya saing bangsa yang potensial untuk terus dikembangkan dan ini merupakan soft power. Dalam konstelasi hubungan internasional atau membangun produk nasional yang memiliki nilai jual tinggi, penanggulangan bencana memiliki keunggulan komparatif dan keunggulan kompetitif sehingga Indonesia dapat menjadi center of excellent kelas dunia ${ }^{18}$

Misalnya, bagaimana soft power yang ditunjukkan dalam keterlibatan Indonesia memberikan bantuan kepada Jepang ketika tsunami melanda Jepang pada bulan Maret 2011, Indonesia sedang melakukan latihan penanggulangan bencana tingkat internasional di Manado (ARF DiREX). Jepang saat itu bertindak sebagai co-chair bersama Indonesia dalam latihan tersebut. Saat itu juga Indonesia terlibat untuk memberikan bantuan kemanusiaan kepada Jepang, bahkan 3 (tiga) bulan kemudian Presiden Republik Indonesia berkunjung ke wilayah terdampak yakni Perfectur Fukushima.

Kesan yang dibuat dari kunjungan Presiden tersebut adalah pernyataan resmi Perdana Menteri Jepang yang sangat berterima kasih kepada Indonesia atas kesediaan untuk memberikan bantuan kemanusiaan kepada Jepang. Indonesia yang saat ini sebagai Partner Strategis Jepang dapat saja atau mungkin dapat ditingkatkan sebagai ally: Artinya bahwa keterlibatan dalam masalah kemanusiaan yang bersifat universal telah mendorong faktor lain yang selama ini menjadi pertimbangan Jepang untuk mengubah preferensinya dalam hubungan bilateral dengan Indonesia, inilah kekuatan soft power tersebut. Bila ini benar-benar terwujud Indonesia akan menjadi juga ally bagi ally-nya Jepang. Sebagai catatan: hubungan bilateral secara berjenjang sebagai berikut, dari bawah adalah: partner, diatasnya strategic partner dan yang paling tinggi adalah ally.

Selain itu, Pemerintah Myanmar meminta bantuan Indonesia untuk membuat UU Penanggulangan Bencana Myanmar. Hampir 70\% isi UU No. 24 Tahun 2007 diadopsi untuk UU di Myanmar. Hal ini menunjukkan betapa kinerja BNPB telah mendapat apresiasi negara lain dan menjadi soft power yang efektif dalam diplomasi Indonesia dengan negara-negara lain. Apresiasi ini semakin dibuktikan dengan ditetapkannya Indonesia sebagai tuan rumah penyelenggaraan Asian Miniterial Conference for Disaster Risk Reduction (AMCDRR ke 5) yang akan dilaksanakan 
pada Oktober 2012 dan akan diikuti 65 negara.

Kunjungan 11 negara kepulauan di kawasan Asia Pasifik ke BNPB dan meminta Indonesia memberikan technical assistance dalam pembangunan sistem informasi bencana dan pendirian AHA Center di Jakarta, dan beberapa bentuk kerjasama antar negara melalui Gentlement Agreement maupun MoU dibidang penanggulangan bencana.

Dengan demikian jelas bahwa penanggulangan bencana dapat menjadi sumber soft power Indonesia dalam pergaulan internasional yang diharapkan akan membantu pelaksanaan diplomasi yang efektif dalam pencapain tujuan dan kepentingan nasional.

\section{KESIMPULAN}

Penanggulangan bencana yang dikoordinasi oleh pemerintah dapat digunakan sebagai soft power bagi pelaksanaan diplomasi Indonesia. Pengakuan dunia terhadap capaian Indonesia dalam penanggulangan bencana merupakan bukti bahwa bangsa Indonesia memiliki daya saing bangsa yang potensial untuk terus dikembangkan dan ini merupakan soft power. Dalam konstelasi hubungan internasional atau membangun produk nasional yang memiliki nilai jual tinggi, penanggulangan bencana memiliki keunggulan komparatif dan keunggulan kompetitif sehingga Indonesia dapat menjadi center of excellent kelas dunia.

\section{CATATAN AKHIR}

1 WALHI : 359 Bencana Alam di Indonesia dalam http:// www.antaranews.com/view/? $\mathrm{i}=1244199032$ diakses pada 1 Maret 2010

2 http://wnw.bnpb.go.id/website/asp/content.asp? id=2 diakses pada 23 April 2012

3 http://www.mediaindonesia.com/read/2012/04/27/315927/293/14/ Awas-Tren-Bencana-Terus-Meningkat-Kerugian-Rp10-Triliun

4 Joseph S. Nye, Jr., Soft Power: The Means to Success in World Politics (New York: Public Affairs, 2004), xi.

5 ibid

6 ibid

7 Joseph S. Nye, Jr, "The Future of Soft Power in US Foreign Policy" dalam Inderjeet Parmar and Michael Cox (ed.), Soft power and US foreign policy : theoretical, historical and contemporary perspectives, Routledge, New York, 2010, h. 4

8 ibid, h. 20

9 Louise K. Comfort, "Disaster: Agent of Diplomacy or Change in International Affairs?", Disaster Journal, 2002
10 Kelman, I. 2006. "Disaster Diplomacy: Hope Despite Evidence?". World Watch Institute Guest Essay, 2006, Kelman, I. 2007. "Disaster diplomacy: Can tragedy help build bridges among countries?" UCAR Quarterly, Fall 2007, p. 6, Kelman, I. 2007. "Weather-Related Disaster Diplomacy". Weather and Society Watch, vol. 1, no. 3, pp. 4,9

11 Kelman, I. 2008. “Disaster Diplomacy: Diplomats should not rely on disasters". vol. 47, 12 April 2008, pp. 8-9

12 Weizhun M, The Apocalypse of the Indian Ocean Earthquake and Tsunami". World Politics and Economy (Chinese Academy of Social Sciences), vol. 6 (in Chinese). Atau dalam Weizhun, M. and Q. Tianshu. 2005. "Disaster Diplomacy: A New Diplomatic Approach?". Shanghai Institute For International Studies International Review, Spring 2005, pp. 111-124 (in Chinese).

13 Lihat dalam http://www.bnpb.go.id/website/asp/content.asp?id=2 diakses pada 13 Juni 2012

14 Makki, 2006

15 Lihat dalam Newsletter Gema BNPB, vol. 2 No 3 November 2011

16 ibid

17 ibid

18 Pernyataan Kepala Badan Nasional Penanggulangan Bencana (BNPB), DR. Syamsul Maarif, Msi dalam http://www.bnpb.go.id/ website/asp/berita_list.asp?id $=612$

\section{REFERENSI}

\section{Buku dan Jurnal}

Comfort, Louise K., "Disaster: Agent of Diplomacy or Change in International Affairs?", Disaster Journal, 2002

Kelman, I., "Disaster Diplomacy: Hope Despite Evidence?". World Watch Institute Guest Essay, 2006

, "Disaster diplomacy: Can tragedy help build bridges among countries?" UCAR Quarterly, Fall 2007

, "Weather-Related Disaster Diplomacy". Weather and Society Watch, vol. 1, no. 3, 2007 , "Disaster Diplomacy: Diplomats should not rely on disasters". vol. 47, 12 April 2008

Nye, Jr , Joseph S., Soft Power: The Means to Success in World Politics, New York: Public Affairs, 2004

Newsletter Gema BNPB, vol. 2 No 3 November 2011

Parmar, Inderjee and Michael Cox (ed.), Soft power and US foreign policy : theoretical, historical and contemporary perspectives, Routledge, New York, 2010

Weizhun M, "The Apocalypse of the Indian Ocean Earthquake and Tsunami". World Politics and Economy (Chinese Academy of Social Sciences), vol. 6 , and Q. Tianshu. 2005. "Disaster Diplomacy: A New

Diplomatic Approach?". Shanghai Institute For International Studies International Review, Spring 2005

\section{Website}

http://www.antaranews.com/view/?i=1244199032

http://www.bnpb.go.id/website/asp/content.asp?id=2

http://www.mediaindonesia.com/read/2012/04/27/315927/293/14 